\title{
Наукова спадщина вчених Центральної дослідної станції штучного осіменіння сільськогосподарських тварин
}

\author{
Юрченко E.I., Національна наукова сільськогосподарська бібліотека
}

У статті висвітлено основні віхи становлення та діяльності Центральної дослідної станції штучного осіменіння сільськогосподарських тварин (1960-1975), іiї завдання у системі селекційно-племінної справи в УРСР. Розкрито наукові досягнення вчених дослідної станції з вивчення й узагальнення досвіду роботи державних племінних станцій і станцій штучного осіменіння УРСР, оптимізації їх організаційної структури. Доведено, що колективом дослідної станції зроблено вагомий внесок у розвиток теоретичних і методологічних основ племінної справи, зокрема таких її елементів, як система лінійного розведення, методи оцінки племінної цінності, селекція за технологічними якостями, прийоми раціонального використання особин із рекордною продуктивністю, що сприяло поліпшенню існуючих порід і типів сільськогосподарських тварин у масштабах республіки. Показано, що одне з основних завдань дослідної станції полягало в удосконаленні технології та техніки штучного осіменіння сільськогосподарських тварин, зокрема оптимізації режимів $\mathrm{i}$ рецептур середовищ для зберігання статевих гамет. Обгрунтовано пріоритет її учених у вивченні фізіології та біології репродуктивної функції сільськогосподарських тварин, запровадженні ефективних способів іiі стимуляції.

Автором аргументовано, що окремі наукові розробки Центральної дослідної станції штучного осіменіння сільськогосподарських тварин не втратили практичного значення на сучасному етапі розвитку тваринництва.

Ключові слова: історія сільськогосподарської дослідної справи; тваринництво; племінна справа; штучне осіменіння; порода; продуктивність; лінійне розведення

\section{Scientific heritage of scientists of the Central Experimental Station of Artificial Insemination of Farm Animals}

\section{Yurchenko E. I., National Scientific Agricultural Library}

The article covers the main milestones of the establishment and activity of the Central Experimental Station for Artificial Insemination of Farm Animals (1960-1975), its tasks in the system of selection and breeding in the Ukrainian SSR. The scientific achievements of scientists of the experimental station on the study and generalization of the experience of the state tribal stations and artificial insemination stations of the Ukrainian SSR, optimization of its organizational structure have revealed. Author has proved that the research station has made a significant contribution to the development of theoretical and methodological foundations of the breeding work. In particular, they proposed such elements as the system of linear breeding, methods for assessing the breeding value, selection according to technological qualities, methods of rational use of individuals with record productivity, which have contributed to the improvement of existing breeds and types of farm animals in the republic. The article shows that one of the main tasks of the experimental station - to improve the technology of artificial insemination of farm animals, in particular optimizing the modes and recipes of media for the storage of sexual gametes. The author has substantiates the priority of its scientists in the study of the physiology and biology of the reproductive function of farm animals, the introduction of effective methods for its stimulation.

The experimental station proposed a number of priority developments, namely, an improved system of linear breeding, methods for assessing the breeding value of animals, techniques for early diagnostics of pregnancy, etc. The introduction of some developments contributed a significant increase of the productive qualities of animals of Ukrainian republic. It was substantiated that some scientific developments of the experimental station, for example, the methods of using inbreeding to increase the productive qualities of animals, methods of rational use of individuals with record productivity, methods of stimulation of reproductive function, have not lost its practical significance at the present stage of livestock development.

The research bases on the comprehensive use of general scientific, structural-functional and historical methods, as well as a broad source base, primarily archival documents.

Keywords: history of agricultural research case; animal husbandry; breeding work; artificial insemination; breed; productivity; linear breeding 


\title{
Научное наследие ученых Центральной опытной станции искусственного осеменения сельскохозяйственных животных
}

\author{
Юрченко Э.И., Национальная научная сельскохозяйственная библиотека
}

В статье освещены основные вехи становления и деятельности Центральной опытной станции искусственного осеменения сельскохозяйственных животных (1960-1975), ее задачи в системе селекционно-племенного дела в УССР. Раскрыты научные достижения ученых опытной станции по изучению и обобщению опыта работы государственных племенных станций и станций искусственного осеменения УССР, оптимизации их организационной структуры. Доказано, что коллективом опытной станции сделан весомый вклад в развитие теоретических и методологических основ племенного дела, в частности таких ее элементов, как система линейного разведения, методы оценки племенной ценности, селекция по технологическим качествам, приемы рационального использования особей с рекордной продуктивностью, что способствовало улучшению существующих пород и типов сельскохозяйственных животных в масштабах республики. Показано, что одна из основных задач опытной станции состояла в усовершенствовании технологии и техники искусственного осеменения сельскохозяйственных животных, в частности оптимизации режимов и рецептур сред для сохранения половых гамет. Обоснован приоритет ее ученых в изучении физиологии и биологии репродуктивной функции сельскохозяйственных животных, внедрении эффективных способов ее стимуляции.

Автором аргументировано, что отдельные научные разработки Центральной опытной станции искусственного осеменения не утратили практического значения на современном этапе развития животноводства.

Ключевые слова: история сельскохозяйственного опытного дела; животноводство; племенное дело; искусственное осеменение; порода; продуктивность; линейное разведение

Постановка проблеми.

$\mathrm{C}$ ільське господарство України залишається провідним сектором економіки, подальший розвиток якого неможливий без належного наукового забезпечення. Тільки визначивши оптимальне поєднання обох складових - науки та виробництва - можна забезпечити продовольчу безпеку нації. Основоположною складовою функціонування вітчизняної галузевої науки є сільськогосподарська дослідна справа, становлення і розвиток якої відбувалися поетапно.

У розробку наукових засад ефективного розвитку сільського господарства в Україні минулого століття вагомий внесок зробили дослідні станції. Зокрема, однією 3 перших дослідних інституцій 3 проблем тваринництва системи Міністерства сільського господарства УРСР $\epsilon$ Центральна дослідна станція штучного осіменіння сільськогосподарських тварин (ЦДСШО). Ї̈ї колективом розвинуто теоретичні та методологічні основи племінної справи, вдосконалено існуючі породи і типи сільськогосподарських тварин, обгрунтувано ефективні методи оцінки ïx племінної цінності та раціонального використання особин із рекордною продуктивністю для поліпшення значних масивів худоби в масштабах всієї республіки. Розроблено методи стимуляції репродуктивної функції сільськогосподарських тварин, оптимізовано технологію та техніку їх штучного осіменіння.

\section{Огляд останніх публікацій.}

Окремі аспекти становлення та діяльності дослідної станції знайшли відображення в наукових працях українських дослідників. Так, у науковому виданні «Історія Інституту розведення і генетики тварин у подіях, фактах, біографіях учених» (2012) висвітлено основні історичні віхи ЦДСШО, яку автори розглядають як предтечу становлення потужного наукового центру з проблем тваринництва, наводять біографічні дані про окремих iii вчених [7]. В. П. Буркат у монографії «Нариси 3 історії інституту» (2008) узагальнює основні напрями творчих пошуків колективу дослідної станції, іiї здобутки з розроблення теоретичних i практичних основ племінної справи в УРСР [6]. Представляє інтерес стаття I. С. Бородай «Центральна дослідна станція штучного осіменіння сільськогосподарських тварин: історія та здобутки» (2015), в якій контекстово розкрито значення окремих наукових розробок учених ЦДСШО для зростання рентабельності галузі вітчизняного тваринництва, збільшення обсягів виробництва високоякісної продукції [5].

Мета статті - систематизувати та узагальнити науковий доробок учених ЦДСШО, обгрунтувати його значення для подальшого розвитку розведення та селекції, генетики та біотехнології відтворення сільськогосподарських тварин, виділити найбільш перспективні наукові розробки, що не втратили практичного значення на сучасному етапі розвитку тваринництва. Для системного i 
повного розкриття предмета дослідження обрано структурно-логічну схему подачі дослідницького матеріалу, що грунтується на загальнонаукових принципах історизму, об'єктивності та наступності, комплексному використанні загальнонаукових, структурно-функціональних та історичних методів. Основу джерельної бази дослідження становлять архівні документи.

Виклад основного матеріалу дослідження. ЦДСШО розпочала свою історію з 1929 р., коли Державну племінну конюшню перевели із с. Терезине у м. Бровари. У 1938 р. на іiі базі створено Київську державну племінну станцію. У воєнні та післявоєнні роки іiі головним завданням було відновлення чисельності поголів'я робочих коней в області для потреб арміі. Для збільшення виробництва тваринницької продукції у 1959 р. Київську державну племінну станцію реорганізовано в Київську станцію по племінній роботі і штучному осіменінню сільськогосподарських тварин. Оскільки розвиток суспільства, досягнення науки, передової практики вимагали нових прийомів і методів ведення галузі, 3 січня 1960 р. на іiі базі створено ЦДСШО [7, с. 33-34].

Цей республіканський науково-дослідний центр мав у своєму складі сім наукових підрозділів: фізіологіі розмноження сільськогосподарських тварин; організації племінної роботи і штучного осіменіння; селекції та схрещування; боротьби 3 яловістю маточного поголів'я; годівлі плідників; техніки штучного осіменіння 3 конструкторським бюро; лабораторію груп крові.

Передусім, для вдосконалення племінних i продуктивних якостей великої рогатої худоби був створений відділ племінної роботи. Серед основних засобів породного вдосконалення значне місце відводили методам чистопородного розведення: лінійному розведенню на основі добору та підбору кращих тварин; створенню нових заводських ліній (Дубка 6501, Ранда 3821, Пантера 691, Апельсина ЧРС-533, Леопарда 2239); методу попередньої оцінки плідників за родоводом; вивченню впливу різних ступенів інбридингу на ріст, молочну продуктивність, тривалість господарського використання корів; плануванню лінійно-групового підбору бугаїв із застосуванням математичних методів і ЕОМ; раціональному використанню кращих плідників для поліпшення значних масивів худоби [6, с. 199].

Ученими відділу розвинуто теоретичні аспекти племінної справи у тваринництві, а саме оптимізовано систему лінійного розведення. Запропоновано метод попередньої оцінки плідників за родоводом та якістю потомства, обгрунтовано зв'язок між ступенем інбридингу та молочною продуктивністю, інтенсивністю росту та тривалістю господарського використання тварин. Розроблено «Методику планування підбору в товарних стадах великої рогатої худоби для господарств зони діяльності станції штучного осіменіння сільськогосподарських тварин», «Методичні рекомендації зі складання п’ятирічного плану селекційно-племінної роботи з великою рогатою худобою для колгоспів і радгоспів зони діяльності станції». Запропоновано оптимальні структуру та параметри діяльності станції штучного осіменіння різних категорій, принципи групування господарств для зони діяльності станції та закріплення за плідниками, рекомендації з організації спецгоспів із вирощування телиць [5, с. 174-175].

На базі відділу племінної роботи дослідної станції відкрито лабораторію із застосування обчислювальної техніки і математичних методів у селекції великої рогатої худоби. Розроблено проект і рекомендації з використання 80- і 45-колонних, перфораційних обчислювальних машин 3 обробки даних бонітування тварин і оцінки за якістю потомства на різних регіональних рівнях; проект та рекомендації 3 обробки матеріалів зі штучного осіменіння і відтворної здатності маточного поголів'я у господарствах. Оптимізовано введення інформації в ЕОМ і перфокарт на перфострічку і розроблено новий макет перфорації, запроваджено у програму оцінки бугаїв за методом «дочка-мати» два нових фрагменти (оцінка-бугаїв за якістю потомства при паруванні з коровами різних ліній і оцінка поєднуваності ліній).

Лабораторією груп крові здійснювалося вдосконалення існуючих порід і типів худоби на основі широкого запровадження імуногенетичних методів для грунтовного аналізу генетичної структури порід, розкриття специфіки їх генофонду, оцінки генетичної консолідації та диференціації. Ученими лабораторії розпочато виробництво реагентів і дослідження груп крові худоби. Доведено неспорідненість походження білоголової української породи із західноєвропейськими породами, визначено ступінь генетичної різноманітності в популяціях симентальської породи. Досліджено генетичний поліморфізм білків за типами трансферинів сироватки крові та молока, їх взаємозв'язок із продуктивністю i відтворною здатністю тварин. Розроблено ефективний спосіб виявлення імунобіологічної поєднуваності тварин при спаровуванні на основі використання в реакціях полівалентної гетероімунної сироватки [4, арк. 68-70]. 
Широкомасштабному запровадженню методу штучного осіменіння сільськогосподарських тварин перешкоджала недосконалість температурного, вологісного та світлового режимів, рецептур середовищ для розрідження і зберігання статевих гамет. 3 цією метою відділом технології та техніки штучного осіменіння вивчено морфологічні зміни у клітинах, зокрема акросомі, що відбулися в процесах їх заморожування та відтавання, вплив прямого сонячного світла та опромінювання різного спектрального складу на їх життєздатність, якість і запліднювальну здатність. Розроблено глюкозо-хелато-цитратне середовище для розрідження та зберігання статевих гамет бугаїв за кімнатної температури, а також на основі його модифікації запропоновано глюкозо-хелато-цитратно-жовткове середовище для кнурів. У 1972 р. вперше за роки експериментальної роботи вдалося отримати живих поросят від свиноматок, осімінених глибокозамороженими статевими гаметами [3, арк. 96].

У складі відділу функціонувало конструкторське бюро, співробітниками якого вдосконалено, розроблено та запроваджено у виробництво понад 20 зразків апаратури і пристроїв для штучного осіменіння самок. У його структурі також створено спеціальний підрозділ, який вивчав проблеми раціональної організації та економічної ефективності штучного осіменіння. Проведено аналіз фактичних даних щодо використання бугаїв у виробничих умовах; обгрунтування економічної ефективності використання заморожених статевих гамет, визначення собівартості виробництва штучного осіменіння, виробничо-фінансових результатів роботи станцій, вивчення впливу використання бугаїв-поліпшувачів на інтенсивність виробництва молока у господарствах.

Основні зусилля вчених відділу боротьби з яловістю спрямовувалися на вирішення питань порушення відтворної функції маточного поголів'я, розробку методів ранньої діагностики тільності, стимуляцію статевої функції худоби тощо. Зокрема, вагоме значення приділялося розробленню та запровадженню ефективних методів стимуляції репродуктивної функції у корів як дійового засобу лікування ряду гінекологічних захворювань та боротьби 3 неплідністю, вивченню впливу активного моціону на стимуляцію їх відтворної функціiі. Розроблено діагностичні режими тільності на основі йодної реакції та внутрішкірної алергічної реакції, новий спосіб діагностики дисфункції матки корів біохімічним методом за допомогою тваринного індикану та ін. [2, арк. 134]
Відділ годівлі плідників проводив дослідження впливу висококонцентратного типу годівлі на стан здоров'я бугаїв та їх репродуктивну функцію. Значна увага приділялася вивченню морфологічних змін, що відбувалися в плідників унаслідок порушення мінерального обміну кісткової тканини. На основі обстеження 42-х державних племінних станцій штучного осіменіння 16 областей УРСР розроблено норми вітамінної терапії плідників. Вивчено вплив різних режимів статевого навантаження плідників на якісні показники їх запліднювальної здатності. Розроблено методику оцінки репродуктивної функції, яка дала змогу порівняти між собою окремих плідників, що належали різним станціям штучного осіменіння. Зусиллями вчених відділу розроблено технологію та проект з організації нормування годівлі бугаїв, технологію і проектування експериментального кормоцеху, проект підлоги з м'якими амортизованими опорами, що знижувала навантаження на кістково-суглобовий апарат кінцівок бугаїв тощо [1, арк. 96].

Відділом біології та фізіології відтворення сільськогосподарських тварин досліджувалися закономірності становлення та розвитку генеративної функції бугаїв, здійснювалися морфологічні дослідження статевих гамет. Значну увагу приділяли пошуку ефективних методів їх оцінки та виготовлення біостимуляторів, вивчення їх впливу на запліднювальну здатність худоби. Проведені грунтовні дослідження з вивчення порушень відтворної функції та розроблено способи ії корекції. На основі анатомо-гістологічних методів та аналізу матеріалів забою корів різного віку вивчали потенційну плодючість корів молочного та комбінованого напрямів продуктивності. У результаті розроблено досить ефективний гормональний метод стимуляції відтворювальної здатності корів на основі застосування сироватки жеребних кобил [3, арк. 124].

Поряд із виконанням наукової тематики співробітниками ЦДСЩО надавалася регулярна методична і практична допомога спеціалістам державних племінних станцій із перспективного планування племінної роботи, організації глибокого заморожування статевих гамет, штучного осіменіння, запровадження сучасних методів діагностики та лікування безпліддя сільськогосподарських тварин.

У січні 1976 р. ЦДСШО перетворена в дослідне господарство «Центральна станція штучного осіменіння сільськогосподарських тварин». Крім осіменіння тварин станція оцінювала якіс- 
ний склад поголів'я (бонітування худоби), комплектувала господарства кадрами селекціонерів, проводила підготовку наявних техніків штучного осіменіння сільськогосподарських тварин, а також оцінку плідників, їх вирощування та значне розширення мережі племінних ферм [7, с. 47].

\section{Висновки.}

Таким чином, вченими ЦДСШО зроблено вагомий внесок у наукове забезпечення розвитку галузі тваринництва УРСР в 1960-1975 рр. Виділено основні напрями, за якими здійснювалися наукові пошуки вчених дослідної станції: 1) організація і планування племінної справи в УРСР; 2) селекція сільськогосподарських тварин; 3) імуногенетичні дослідження в тваринництві; 4) удосконалення технології штучного осіменіння; 5) біологія і фізіологія розмноження сільськогосподарських тварин; 6) інформатизація селекційного процесу та ін. Дослідною станцією запропоновано низку пріоритетних розробок: удосконалену систе- му лінійного розведення, методи оцінки племінної цінності тварин, методику планування підбору в племінних i товарних стадах, спосіб виявлення імунобіологічної поєднуваності тварин, прийоми ранньої діагностики тільності, технологію та проект 3 організації нормування годівлі бугаїв, технологію i проектування експериментального кормоцеху тощо. Запровадження наукових розробок учених ЦДСШО сприяло значному зростанню продуктивних і племінних якостей тварин як у племінних господарствах зони іiі обслуговування, так і в масштабах усієї республіки. Обгрунтовано, що окремі наукові розробки дослідної станції, зокрема методи застосування споріднених парувань з метою зростання продуктивних і племінних якостей тварин, прийоми раціонального використання особин з рекордною продуктивністю, прийоми стимуляції репродуктивної функції, не втратили свого практичного значення на сучасному етапі розвитку тваринництва.

\section{БІБІЛІОГРАФІЧНІ ПОСИЛАННЯ}

1. Архів Інституту розведення і генетики тварин (ІРГТ). Звіт про виконання тематичного плану науково-дослідної роботи за 1966 р. // ЦДСШО. - Бровари, 1967. - 266 арк.

2. Архів ІРГТ. Звіт про виконання тематичного плану науково-дослідної роботи за 1968 р. // ЦДСШО. - Бровари, 1969. - 27 арк.

3. Там само. Звіт про виконання тематичного плану науково-дослідної роботи за 1970 р. // ЦДСШО. - Бровари, 1971. - 286 арк.

4. Там само. Звіт про виконання тематичного плану науково-дослідної роботи за 1973 р. // ЦДСШО. - Бровари, 1974. - 275 арк.

5. Бородай І. С. Центральна дослідна станція штучного осіменіння сільськогосподарських тварин: історія та здобутки / І. С. Бородай // Переяславський літопис. - 2015. - № 7. - С. 174-177.

6. Буркат В. П. Нариси з історії інституту / В. П. Буркат, І. С. Бородай - Київ: Аграрна наука, 2008. - 555 с.

7. Коваленко Г. С. Центральна дослідна станція штучного осіменіння сільськогосподарських тварин / Г. С. Коваленко, І. С. Бородай, А. О. Шейкіна // Історія Інституту розведення і генетики тварин у подіях, фактах, біографіях учених. - Бориспіль: Люксар, 2012. - С. 33-50.

8. Курта В. Київське обласне державне підприємство з племінної справи в тваринництві (ОДПП) / В. Курта // Броварська минувщина. - Бровари, 2003. - С. 296-299.

9. Центральна дослідна станція штучного осіменіння сільськогосподарських тварин // Тваринництво України. 1966. - № 1. - C. 60-63.

\section{REFERENCES}

1. Arhiv Instytutu rozvedennja i genetyky tvaryn (IRGT) [Archive of Institute of Animal Breeding and Genetics (IRGT)]. (1967). Zvit pro vykonannja tematychnogo planu naukovo-doslidnoi' roboty za $1966 \mathrm{r}$. [Report on the implementation of the thematic plan of research work for 1966]. Brovary, 266 [in Ukrainian].

2. Arhiv IRGT [Archive of IABG]. (1969). Zvit pro vykonannja tematychnogo planu naukovo-doslidnoi' roboty za 1968 r. [Report on the implementation of the thematic plan of research work for 1968]. Brovary, 27 [in Ukrainian].

3. Archiv IRGT [Archive of IABG]. (1971). Zvit pro vykonannja tematychnogo planu naukovo-doslidnoi' roboty za 1970 r. [Report on the implementation of the thematic plan of research work for 1970]. Brovary, 286 [in Ukrainian].

4. Arhiv IRGT [Archive of IABG]. (1974). Zvit pro vykonannja tematychnogo planu naukovo-doslidnoi' roboty za 1973 r. [Report on the implementation of the thematic plan of research work for 1973]. Brovary, 275 [in Ukrainian].

5. Borodai, I.S. (2015). Central'na doslidna stancija shtuchnogo osimeninnja sil's'kogospodars'kyh tvaryn: istorija ta zdobutky [Central research station for artificial insemination of farm animals]. ч 174-177 [in Ukrainian]. 
6. Burkat, V.P., \& Borodai, I.S. (2008). Narysy z istorii instytutu: monohrafiia [Essays on the history of the institute]. Kyiv [in Ukrainian].

7. Kovalenko, H.S., Borodai, I.S., \& Sheikina, O.A. (2012). Tsentralna doslidna stantsiia shtuchnoho osimeninnia silskohospodarskykh tvaryn [Central research station for artificial insemination of farm animals]. Istoriia Instytutu rozvedennia i henetyky tvaryn u podiiakh, faktakh, biohrafiiakh uchenykh [History of the Institute of Animal Breeding and Genetics in Events, Facts, Biographies of Scientists]. Boryspil, 33-50 [in Ukrainian].

8. Kurta, V. (2003). Kyi’vs'ke oblasne derzhavne pidpryjemstvo z pleminnoi' spravy v tvarynnyctvi (ODPP) [Kiev regional state breeding enterprise in livestock breeding (RSEB)]. Brovars'ka mynuvshhyna [Brovarsky past]. Brovary, 296-299 [in Ukrainian].

9. Central'na doslidna stancija shtuchnogo osimeninnja sil's'kogospodars'kyh tvaryn [Central research station for artificial insemination of farm animals]. (1966). Tvarynnyctvo Ukrai'ny, 1, 60-63 [in Ukrainian].

\section{Юрченко Едуард Ігорович}

\section{Аспірант}

Національна наукова сільськогосподарська бібліотека НААН

03127, м. Київ, вул. Героїв Оборони, 10

\section{Yurchenko Eduard}

Post-graduate student

National Scientific Agricultural Library of NAAS

10, Heroiv Oborony St., Kyiv, 03127, Ukraine

Email: yurchenko_ei@ukr.net

Цитування: Юрченко Е. І. Наукова спадщина вчених Центральної дослідної станції штучного осіменіння сільськогосподарських тварин / Е. І. Юрченко // Науково-теоретичний альманах «Грані». - 2018. T. 21. - № 5. - C. 84-89.

Citation: Yurchenko, E.I. (2018). Naukova spadshchyna vchenykh Tsentralnoi doslidnoi stantsii shtuchnoho osimeninnia silskohospodarskykh tvaryn [Scientific heritage of scientists of the Central Experimental Station of Artificial Insemination of Farm Animals ]. Scientific and theoretical almanac «Grani», 21(5), 84-89. 